\title{
Benign Tumors of the Maxillary Bones (About 30 Cases)
}

Othmane Bouanani", Bouchra Dani, Salma Benazzou, Malik Boulaadas

Department of Maxillofacial Surgery, Hospital of Specialities-Rabat, Faculty of Medicine and Pharmacy-Rabat, Mohamed V University, Rabat, Morocco

DOI: $10.36347 /$ sjams.2020.v08i11.020

| Received: 30.03 .2020 | Accepted: 06.04.2020 | Published: 16.11.2020

*Corresponding author: Othmane Bouanani

Abstract

Original Research Article

Introduction: Benign neoplasms of the maxillary include various histological entities. In the vast majority of cases, these tumours are related to elements of the dental system and are referred to as odontogenic tumours. More rarely, they are bone tumors themselves, then called non-odontogenic tumors. Materials and Methods: Our study is a retrospective study of 30 cases of benign neoplasms of the maxillary, collided within the maxillofacial surgery department of the Specialty Hospital-Rabat, between January 2014 and February 2018. Results: Data analysis found a frequency of odontogenic tumours that represented $67 \%$ versus $33 \%$ of non-odontogenic tumours. The average age was 24 years with no gender predominance. The consultation period was 3 years. Facial swelling was the master symptom, sometimes associated with dental signs in $35 \%$ of cases. All our patients received a radiological check-up. Treatment was conservative in $75 \%$ of cases. The confirmation of the diagnosis was always based on the anatomopathological examination of the surgical removal part. The evolution was generally favourable in $70 \%$ of our patients, without recurrence. Discussion: Benign neoplasms of the maxillary have a wide range of histological features and can be divided into 2 major groups: odontogenic and non-odontogenic tumours. Despite their great diversity, the clinical description of these tumors is unambiguous, and it is often the radiological record that will allow to evoke the diagnosis whose confirmation is indispensable by the anatomopathological examination; surgical treatment is usually conservative with good postoperative evolution.

Keywords: Tumor, Maxilla, Mandible, Benign.

Copyright $\odot 2020$ The Author(s): This is an open-access article distributed under the terms of the Creative Commons Attribution 4.0 International License (CC BY-NC 4.0) which permits unrestricted use, distribution, and reproduction in any medium for non-commercial use provided the original author and source are credited.

\section{INTRODUCTION}

Benign neoplasms of the maxilla represents various histological entities whose clinical and radiological appearance can be revelatory they are most often related to the dental system and are called odontogenic tumors, Non-odontogenic tumours are bone tumours themselves; treatment varies according to histological type but is usually conservative.

\section{Materials ANd Methods}

Our study is a retrospective study carried out within the department of maxillofacial surgery at the Rabat specialty hospital.

Having collected 30 cases of benign maxillary tumors over a period of 4 years from January 2016 to February 2020.

\section{RESULTS}

The average age of our patients was 30 years with extremes ranging from 17 to 58 years In our series we did not notice a predominance of sex.
Jugal swelling was found in $100 \%$ of cases, pain was present in $20 \%$ of cases, dental signs had type of neuralgia or dental mobility were present in $33 \%$ of cases and endobuccal examination has objectified inflammation of the mucosa in relation to the tumor in $13 \%$ of cases.

The mandible was affected in $87 \%$ of cases versus $13 \%$ of maxillary involvement, the size of the tumor exceeded $4 \mathrm{~cm}$ in $76 \%$ of cases. The orthopantomogram was started in $87 \%$ of our patients and having objected: an osteolytic image in $87 \%$ of cases a mixed image was reduced in $13 \%$ of cases.

The CT scan was requested in $33 \%$ of our patients especially in the case of maxillary involvement, but also to evaluate the cortical lysis and the relationship with the adjacent structures; Contrast injection was used to assess the vascularistaion of lesions and to determine the vascular character of the tumor. 
All our patients benefited from a surgical treatment that was conservative in $54 \%$ of cases and radical in $46 \%$ of cases fibula loose flap was used to reconstruct mandibular loss in $43 \%$ of cases, osteosynthese plaque was used in $10 \%$ of cases especially in non-interruptive bone resection with retention of the mandibular basilar border, the predominant histological type was ameloblastoma in $40 \%$ of cases, followed by radiculodental cyst in $23 \%$ of cases, giant cells granuloma in $12 \%$ of cases;myxoma odonogene $10 \%$, anevrysmal cyst $10 \%$, Keratocyst occupied a percentage of $3 \%$.

The average decrease of the post-operative follow-up was of 1 year: 3 patients were lost in sight a post-operative infection was found in $7 \%$ of cases no cases of tumour recurrence or malignant degeneration were noted.

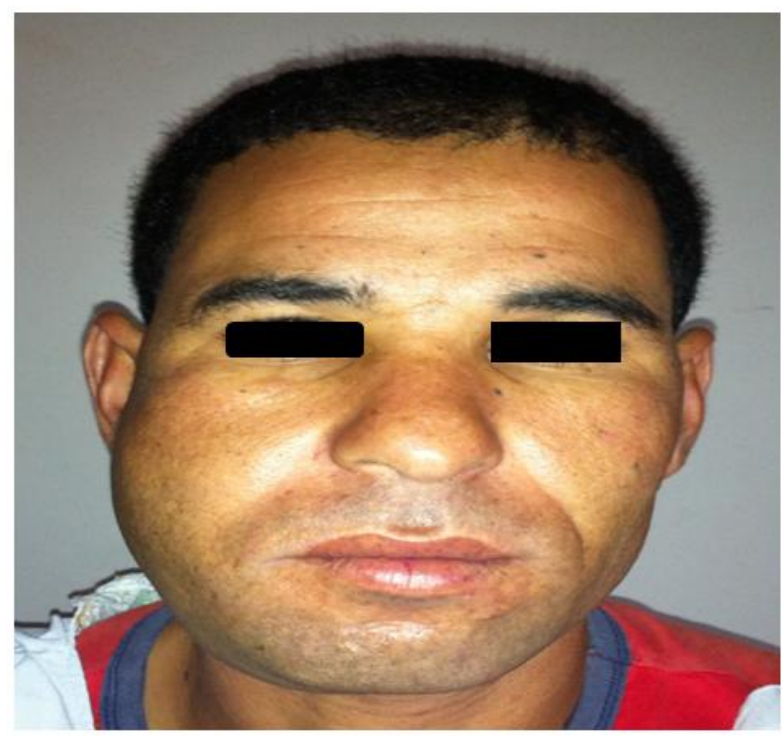

Fig-1: Image objectifying right jugal swelling

\section{Tumor localisation}

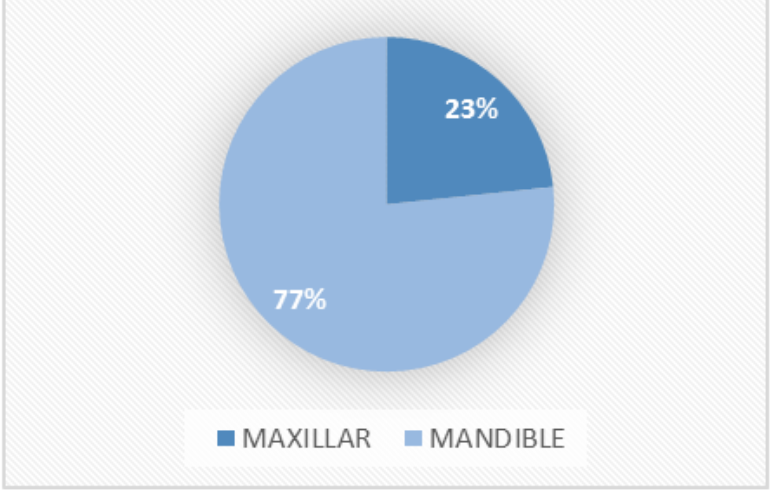

Fig-2: Tumor localisation

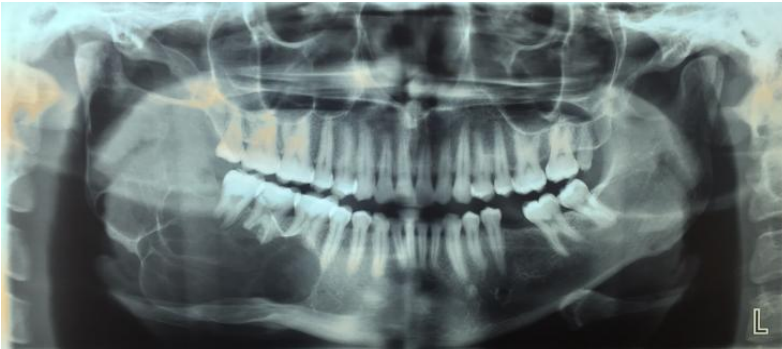

Fig-3: Osteolytic image of the right hemimandible

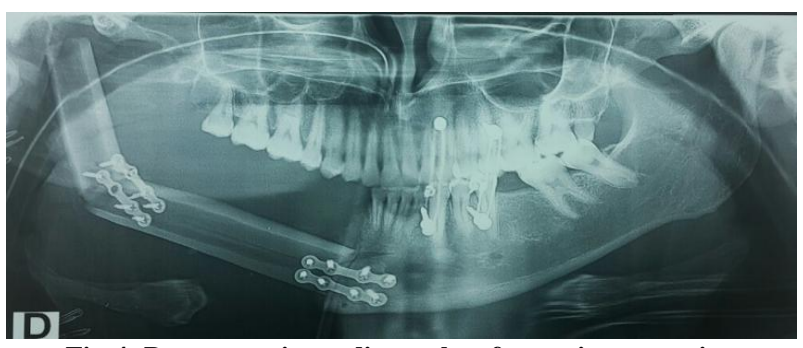

Fig-4: Post-operative radiography after an interruptrice hemimandibulectomy and reconstruction by a loose flap of the fibula

\section{DisCUSSION}

Benign maxillary tumors represent a rare entity [1-5], the requirement in our series was 7 cases/year, result identical to that of KOVI [5] and similar to that of JANAH [1] and KOVI contrary to the series of RAKOTOARISOA where the incidence was 14 cases/yearthe mean age of our patients was 30 years of age result which is similar to other studies consistent with the literature data since the incidence of these tumors remains important during the 2nd and 3rd decades [6-10] in our series we did not find a predominance of sex; same result found in the series of E.kpemsi [7], contrary to the studies of RAKOTOARISOA [6], AYANECHI [10] and AVELAR [12] tumor being the preponderant functional sign in all series the clinical examination has objected a tumor size that exceeds $4 \mathrm{~cm}$ in $67 \%$ of cases, a result similar to that of heymans [18] and agbokponto [13]

Inflammation of the oral mucosa was found in only $14 \%$ of cases (related to ameloblasoma) the predominance of mandibular involvement was also found in most of the series of the litteratute with as leader ameloblastome what can be explained by the importance of spongy tissue at the mandibular level.

The absence of adenopathy and sensitivity disorders was found in all studies revealing the benign character of the lesions.

The OPT is the reference and first-line examination which allows an analysis of the dental apparatus, the bone frame; the temporomandibular articulation and the lower dental alveolo channel (60). In $85 \%$ of the patients in our series, the gap was lower than in the lompo (36) series, $87 \%$ and $100 \%$ TAGBA (33). 
The CT scan of the facial mass was required in case of maxillary localization as well as to analyse the cortical lysis, a periosteal reaction, the relationship with the adjacent structures. Contrast injection also allowed the study of relationships with vascular structures and the vascular nature of the lesion $[15,16]$; Performed in $33 \%$ of our patients against the Tagba series or only $2 \%$ of the patients benefited from the CT $\mathrm{v}$ the high cost of this exam at BENIN [2].

Due to aesthetic concerns and to avoid scarring, the endooral approach was performed in $54 \%$ of the patients in our series, for the same reason the endooral approach was repeated respectively in the LOMPO [11] and RUHIN series 80 AND 84\%.

The cervical approach was reserved for large tumors in case of bone resection, which allowed a wider view and facilitated surgical reconstruction.

Conservative treatment is the treatment of choice in such a way as to preserve the bone capital and it consists of an enucleation with a simple or supported curettage [7]; in our series it was carried out in 53\% of cases, conservative treatment can only be used in case of limited lesion of waist with low aggressiveness.

As for radical surgery, it helps to avoid recurrences, iterative surgeries or any ventolar carcinomatous transformation.

In our series we opted for radical surgery in $43 \%$ of cases in case of locally aggressive tumor with a high risk of recurrence (ameloblastoma; granuloma has giant cells..). in most authors the radical surgery is the most appropriate to avoid recurrences carried out in $61 \%$ of cases in the TAGBA [8] series AND $70 \%$ in the LOMPO series [11].

In our series $43 \%$ of our patients benefited from a reconstruction by a loose flap of the fibula (loss of mandibular substance due to ameloblastma and odontogenic myxoma) in the RUHIN series $15 \%$ of the patients benefited from a reconstruction by a free flap of the fibula [18] and in the BRAGA series the figure was $10 \%$ [19].

Odontogenic tumors are the most common entity in our series found in $76 \%$ of cases, while in the other series in the literature this frequency remains the highest [11]. for cystic lesions there is also a predominance of radiculodental cysts found at the maxillomandibular level in $23 \%$ of cases.

Infection was reversed in $10 \%$ and $17 \%$ of cases respectively in the LOMPO [11] and TAGBA [8] series.

Infection was found in $7 \%$ of cases treated with antibiotic therapy and no case of tumor recurrence was found in our series, however TAGBA [8] reports a case of recurrence of ameloblastoma treated with conservative surgery, a rate that reached $3,3 \%$ in the LOMPO [11] series especially for ameloblastomas.

No cases of malignant transformation have been noted in our series which join the literature data with a low rate not exceeding $10 \%$ [8].

\section{CONCLUSION}

Benign maxillary tumors are relatively rare, their clinical and radiological aspects are relatively evocative with several histological types that condition surgical treatment. Evolution is generally good in case of adequat treatment.

\section{REFERENCES}

1. Janah A, Saidi A, Bourjilat M, Benhaddou A, Chekkouri IA. Les kystes et les tumeurs bénignes des maxillaires. Corrélations anatomoradiologiques. Mag Méd. 2001;21(359):346-348.

2. Al-Khateeb T, Hamasha AA, Almasri NM. Oral and maxillofacial tumours in north Jordanian children and adolescents: a retrospective analysis over 10 years. International journal of oral and maxillofacial surgery. 2003 Feb 1;32(1):78-83.

3. Dodge OG. Tumors of the jaw. Cancer, 1965;18:205-215.

4. Dehner LP. Tumors of the mandible and maxilla in children. Cancer, 1973;31: 364-383.

5. Kovi J, Parth MC, Laing N. Tumors of the mandible and maxilla. Cancer, 1966; 19:13011307.

6. Rakotoarisoa AH, Rakotoarivony AE, Razafindrakoto RM, Rakotoarison RA, Razakamaharavo AZ, Razafindrabe JA. Tumeurs et kystes odontogènes observés au CHU d'Antananarivo de janvier 2006 à mars 2008;7:3240.

7. Kpemissi E, Amana B, Tchandana K. Tumeurs des maxillaires: aspects épidémiologiques, diagnostiques et thérapeutiques: à propos de 91 cas. Mali Med, 2009- malimedical.org

8. Tagba E, Sy A, Ndiaye M. Aspects diagnostiques et résultats du traitement chirurgical des tumeurs maxillomandibulaires: à propos de 23 cas Journal Africain du cancer, 2014 Springer.

9. Abdennour S, Benhalima H. Les tumeurs odontogènes bénignes : analyse épidémiologique de 97 cas dans la population algérienne Rev Stomat Chi Maxillofac Chir Oral, 2013;114:67-71.

10. Anyanechi CE, Saheeb BD. A review of 156 odontogenic tumours in Calabar, Nigeria. Ghana medical journal. 2014;48(3):163-7.

11. Lompo O. Les tumeurs bénignes et kystes maxillomandibulairesaux CHU-YO au Burkina Faso et au CNHU-HKM au Benin : aspects épidémiologiques, cliniques thérapeutiques et 
évolutifs thèse pour l'obtention du doctorat en médecine, 2012.

12. Avelar RL, Antunes AA, Santos TD, Andrade ES, Dourado E. Tumores odontogênicos: estudo clínico-patológico de 238 casos. Revista Brasileira de Otorrinolaringologia. 2008 Oct;74(5):668-73.

13. Agbokponto A. Tumeurs bénignes des maxillaires: Aspects cliniques et thérapeutiques; A propos de 64 cas recensés dans le service d'ORL-CCMF du CNHU-HKM de Cotonou. Faculté des sciences de la Santé, Université d'Abomey-Calavi. 2010. Thèse de Doctorat en Médecine. $\mathrm{n}^{\circ} 1540$.

14. Nitassi S, Boulaadass M, Tobi I, Essakali L, Kzadri M. Améloblastome: diagnostic et traitement. A propos de 26 cas. Med. Buccale Chir. Buccale. 2009;15:93-100.
15. Benhalima H, Lazrak A. Diagnostic des tumeurs et pseudo-tumeurs mandibulaire, 2002.

16. Zrig A. Les images condensantes des maxillaires. JFR, 2011.

17. Ruhin B, Guilbert F, Bertrand JC. Traitement des kystes, tumeurs et pseudotumeurs bénignes des maxillaures EMC-Stomatologie 1, 2005:42-59.

18. Heymens O, Nelissen X, Gilon Y, Jacquemin D. Myxoma of mandible. A case report. Rev Stomatol Chir Maxillofac, 2008 Sept, 103(4):239-41.

19. Braga-Silva J, Jaeger MRO, Favalli PPS. Reconstruction mandibulaire: les lambeaux microchirurgicaux de crête iliaque et péroné Annales de chirurgie plastique esthétique 50; 2005:49-55. 